\title{
Trace Metal Content of Sediments Close to Mine Sites in the Andean Region
}

\author{
Cristina Yacoub, ${ }^{1}$ Agustí Pérez-Foguet, ${ }^{2}$ and Nuria Miralles ${ }^{1,3}$ \\ ${ }^{1}$ Grup de Recerca en Cooperació i Desenvolupament Humà (GRECDH), Departament d'Enginyeria Química, ETSEIB, \\ Universitat Politècnica de Catalunya, Avenida Diagonal 647, 08028 Barcelona, Spain \\ ${ }^{2}$ GRECDH-LaCÁN, Departament de Matemàtica Aplicada 3, ETSECCPB, Universitat Politècnica de Catalunya, Jordi Girona 1-3, \\ 08034 Barcelona, Spain \\ ${ }^{3}$ Departament d'Enginyeria Química, Universitat Politècnica de Catalunya, Avenida Diagonal 647, Edifici H Planta 4a, \\ 08028 Barcelona, Spain
}

Correspondence should be addressed to Nuria Miralles, nuria.miralles@upc.edu

Received 28 October 2011; Accepted 29 November 2011

Academic Editors: T. Brock, G.-C. Fang, and K. Kannan

Copyright (c) 2012 Cristina Yacoub et al. This is an open access article distributed under the Creative Commons Attribution License, which permits unrestricted use, distribution, and reproduction in any medium, provided the original work is properly cited.

This study is a preliminary examination of heavy metal pollution in sediments close to two mine sites in the upper part of the Jequetepeque River Basin, Peru. Sediment concentrations of $\mathrm{Al}, \mathrm{As}, \mathrm{Cd}, \mathrm{Cu}, \mathrm{Cr}, \mathrm{Fe}, \mathrm{Hg}, \mathrm{Ni}, \mathrm{Pb}, \mathrm{Sb}, \mathrm{Sn}$, and $\mathrm{Zn}$ were analyzed. A comparative study of the trace metal content of sediments shows that the highest concentrations are found at the closest points to the mine sites in both cases. The sediment quality analysis was performed using the threshold effect level of the Canadian guidelines (TEL). The sediment samples analyzed show that potential ecological risk is caused frequently at both sites by $\mathrm{As}, \mathrm{Cd}, \mathrm{Cu}, \mathrm{Hg}, \mathrm{Pb}$, and $\mathrm{Zn}$. The long-term influence of sediment metals in the environment is also assessed by sequential extraction scheme analysis (SES). The availability of metals in sediments is assessed, and it is considered a significant threat to the environment for As, Cd, and $\mathrm{Sb}$ close to one mine site and $\mathrm{Cr}$ and $\mathrm{Hg}$ close to the other mine site. Statistical analysis of sediment samples provides a characterization of both subbasins, showing low concentrations of a specific set of metals and identifies the main characteristics of the different pollution sources. A tentative relationship between pollution sources and possible ecological risk is established.

\section{Introduction}

Mine water pollution is a widespread international problem and one of the most severe forms of aquatic pollution. Specifically, acid mine drainage is one of the main causes of water pollution worldwide and has emerged as a major environmental problem over the last few decades [1-5]. Current and traditional mining activities have contaminated river channels and floodplains in many parts of the world with concentrations of metal-rich waste that may pose a risk to human livelihood and sustainable development [6]. Sediments in rivers polluted by acid mining drainage consist of a complex mixture of various geochemical fractions containing potentially toxic metals. The mobility of such hazardous metals is highly dependent on their specific chemical forms or different binding forms rather than on total element concentrations. Consequently, knowledge of metal partitioning between the different geochemical fractions is particularly useful for determining the bioavailable fraction and the risk of ecotoxicity [7-10].

South America has a long history of mining and many of the oldest mines are still active. Production in this sector has increased dramatically over the last fifteen years, accompanied by changes in public policy, many related social conflicts, shifts in patterns of natural resource and land ownership, and a rapid expansion of business-led social responsibility including the promotion of community development programs [11]. Due to the geomorphologic characteristics of the Andean region, there is a strong presence of trace metals in the environment. For this reason, mining activities are sometimes understood as just one more contributor to a total amount of trace metals. Despite of sediment relevance to assess mine pollution, sediment analyses are not usual in 
the region. This is the case of Jequetepeque River Basin (Peru), where sediment analyses have not been performed previous to the study presented here. In this context, the aim of this study is to contribute to the knowledge of availability of trace metals close to mine sites, and if it represents a possible toxic hazard or not. Due to some constraints, most notably economic resources, we were limited to only a few points of monitoring in spite of the intensive literature research of the site made before.

Sequential extraction schemes (SESs) are widely used for assessing trace metal mobilization and bioavailability by providing information on the distribution or partitioning of trace metals in soils and sediments. This information is particularly valuable in risk assessment and is not provided by sediment digestion procedures. SES assesses the availability, mobility, or persistence of trace metals to determine levels of retention and release (relative to readsorption and redistribution processes). In 1987, the Community Bureau of Reference (BCR) (now the Standards, Measurements and Testing Programme, SM\&T) produced a standard protocol for the extraction of metals from soils and sediments to solve the problems caused by the wide variety of SES in existence at that time and the lack of comparability of results [3, 12-15]. The protocol uses fixed operation conditions (i.e., extractant agents, time and form of shaking, operation sequence, etc.), which ensures that results obtained in different laboratories can be compared accurately [16]. Therefore, BCR-SES protocol is normally used to study heavy metal distribution in sediments [14, 17-22].

Following this protocol, study areas and monitoring points were selected by a previous revision of the area of interest. Metal concentrations in sediment samples were performed by taking nine points located close to mine sites in Cajamarca, Peru. For this purpose, a specific monitoring campaign was designed based on the guidelines provided by the United States Environmental Protection Agency [23-29]. BCR-SES was used to identify chemically active forms in the sediment samples [20]. The sediment concentrations of $\mathrm{Al}$, $\mathrm{As}, \mathrm{Cd}, \mathrm{Cu}, \mathrm{Cr}, \mathrm{Fe}, \mathrm{Hg}, \mathrm{Ni}, \mathrm{Pb}, \mathrm{Sb}, \mathrm{Sn}$, and $\mathrm{Zn}$ were analyzed for each fraction of the SES analysis. BCR-SES analysis for these metals and metalloids was performed following considerations from the literature $[3,15]$. The sediment concentrations were compared with the concentrations established in the Canadian Sediment Quality Guidelines for the Protection of Aquatic Life [30], and a potential ecological risk was determined. A comparative study of metal concentrations and the corresponding ecological risks was made based on sediments collected from the mainstream and tributaries of two subbasins [31]. The sediment analysis data was processed using principal component analysis (PCA) and hierarchical cluster analysis (HCA), which identify similarities and differences between the data, to obtain more information about the pollution sources.

\section{Methodology}

2.1. Study Area. The Jequetepeque watershed $\left(4372.5 \mathrm{~km}^{2}\right)$ is located in northern Peru (Figure 1). The river flows east to west from the Andes to the Pacific Ocean. Annual average precipitation on watershed ranges from 0 to $1100 \mathrm{~mm}$ and its altitude varies from 0 to 4188 meters above sea level (m.a.s.l.). The Gallito Ciego reservoir (400 m.a.s.l.) separates the upper-middle part of the watershed from the lower part and stores water used to supply the population of large coastal cities and for extensive agriculture. The uppermiddle part of the watershed covers an area of $3564.8 \mathrm{~km}^{2}$. Approximately $80 \%$ of the population is rural. The main activities are agriculture, livestock, and mining, and there are no other productive activities such as tanning or intensive farming [32]. Two study areas were selected, each one in a different subbasin: Llapa and Rejo (see Figure 1). The Llapa subbasin includes the Sipán SL mine and the Rejo subbasin includes part of the Minera Yanacocha SRL mine. In both mines, gold extraction has been performed with cyanide leaching and the Sipán SL mine was closed in 2005. Thus, trace metal release could be caused by mining activities or could simply be due to the naturally high levels found in the Andes.

The study areas were selected on the basis of the following criteria: (i) USEPA Guidelines [25-29]; (ii) proximity to the main mining activities; (iii) hydrology, geology, geomorphology, erosion, and topography [32-35]; (iv) previous evidence of toxicology or spillage; (v) available data from studies of water quality [33, 34, 36]; (vi) feasibility of monitoring activities, particularly regarding physical access to sites and approval of local residents.

2.2. Sediment Samples. This survey was conducted in October 2008. Nine sampling points were established in the two study areas following above-mentioned criteria, 5 in the Llapa subbasin and 4 in the Rejo subbasin (see Figure 1). In the Llapa subbasin, points Y1, Y2, and Y3 were located in the mainstream and $\mathrm{Y} 4$ and $\mathrm{Y} 5$ in tributaries (which are assumed to come into contact with acid drainage). Y1 was upstream of the contact area with polluted water. In the Rejo subbasin, points R1, R2, and R3 were in the mainstream and R4 was in a tributary (without known contact with polluted waters). A total of 10 sediment samples were collected in plastic bottles using a core sampler. One sample was taken as a field replicate of sediments following the USEPA recommendations $[28,29]$. Samples were taken from the nearest point on the river bank, were stored in plastic bottles, and kept cool in the field [28]. The sediment samples were surface sediments $(0-5 \mathrm{~cm}$ of depth). Three sediment subsamples were collected and mixed at each site (within $100 \mathrm{~m}$ of the river) as a composite sampling procedure in order to obtain a representative sample [28]. The sub-samples were mixed in the field in a tray with a total volume of $1 \mathrm{~L}$. The sediments were composed mostly of clay and silt, and the percentage of rocks varies depending on the sampling point, from $0.9 \%$ to $85 \%$, with most cases around 6\%. Electrical conductivity and $\mathrm{pH}$ were directly measured in the field. The sediment samples were analyzed at the Corrosion and Protection Institute Laboratory of the Pontifical Catholic University of Peru in Lima.

Sediment samples were dried at $60^{\circ} \mathrm{C}$ until constant weight [37] and sieved to obtain a particle size of $<63 \mu \mathrm{m}$ 


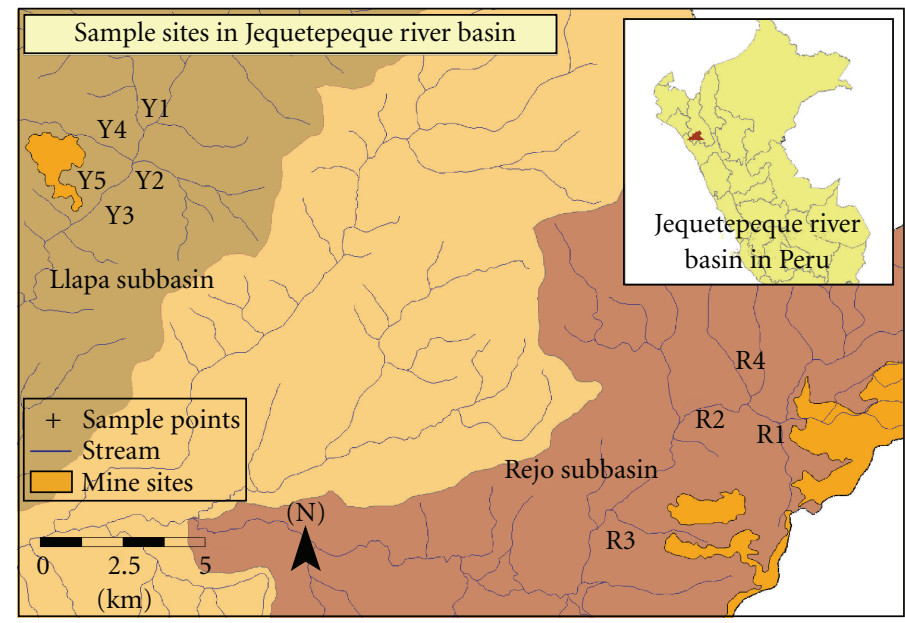

FIGURE 1: Map of monitoring sites. Y1, Y2, Y3, Y4, and Y5 in Llapa subbasin and R1, R2, R3, and R4 in Rejo subbasin in the Jequetepeque River Basin, Cajamarca, Peru.

(UNE Standard 7050), which retains trace metals [12-14, 3741]. Dried samples were stored in polyethylene bottles.

2.3. Sequential Extraction Scheme and Sediment Analysis. The BCR procedure, together with its related phases and its respective reagents, is summarized below and full details can be found elsewhere $[15,16,20]$.

Step 1 consists in extracting exchangeable water- and acid-soluble species, which are weakly bound metals retained on the sediment surface by relatively weak electrostatic interactions and can be released by changes in ionic competition or affected by small $\mathrm{pH}$ changes. For each sample, $40 \mathrm{~mL}$ of $0.11 \mathrm{~mol} \mathrm{dm}^{-3}$ acetic acid was added to $1 \mathrm{~g}$ of sediment in a $100 \mathrm{~mL}$ centrifuge tube and shaken for $16 \mathrm{~h}$ at room temperature. The extract was separated from the solid residue by centrifugation and decantation of the supernatant liquid into a high density, polyethylene container. The container was stopped and the extract was stored at $4^{\circ} \mathrm{C}$. The residue was washed by adding $20 \mathrm{~mL}$ of water, shaking for $15 \mathrm{~min}$, and finally centrifuging the resulting suspension.

Step 2 consists in extracting reducible species contained in iron and manganese oxides, which are released due to their instability under reducing conditions. In this step, $40 \mathrm{~mL}$ of $0.1 \mathrm{~mol} \mathrm{dm}^{-3}$ hydroxylamine chloride (adjusted to $\mathrm{pH} 2$ with nitric acid) was added to the residue from Step 1 in the centrifuge tube, and the extraction and wash were performed as described above.

Step 3 consists in extracting oxidizable species, which are trace elements bound to various forms of organic matter. The degradation of organic matter under oxidizing conditions is responsible for releasing trace elements. $10 \mathrm{~mL}$ of solution $8.8 \mathrm{~mol} \mathrm{dm}^{-3} \mathrm{H}_{2} \mathrm{O}_{2}$ (adjusted to $\mathrm{pH} 2$ with nitric acid) was added carefully, in small aliquots to avoid losses due to violent reaction, to the residue from Step 2 in the centrifuge tube. The sample was digested at room temperature for $1 \mathrm{~h}$ with occasional manual shaking. After that, we used a water coating (about $85^{\circ} \mathrm{C}$ ) until evaporation. When the samples were dry, the entire process was repeated. Next we added $50 \mathrm{~mL}$ of ammonium acetate $1 \mathrm{~mol} \mathrm{dm}^{-3}$, and it was shaken for $16 \mathrm{~h}$ at room temperature. Again, the extraction was performed as described in Step 1.

Step 4 consists in extracting residual species, which are constituent elements of the lattice mineral structure that are not easily released into the water. $5 \mathrm{~mL}$ of $\mathrm{HCl}$ and $15 \mathrm{~mL}$ of $\mathrm{HNO}_{3}$ (both trace analysis quality) were added in a Pyrex container in a sand coating for $3 \mathrm{~h}$ at $150^{\circ} \mathrm{C}$. Finally, the sample was centrifuged and the supernatant was separated in a polyethylene tube and kept at $4^{\circ} \mathrm{C}$ until the analyses were performed.

The consideration of the metal and metalloid content in sample sediments was obtained as the sum of each step, taking into account that no significant differences between total metal content by aqua regia digestions and the sum of the extracted metals by BCR procedures [12]. Assessment of trace metal loads released from mining was carried out by analyzing the ratios between the average mainstream and tributary values of metal content in sediments. In order to evaluate the associated risk of the metal loads, the available metal fraction was calculated as the sum of the three first fractions of SES $[13,14,42]$.

Metal contents were determined by atomic absorption spectrometry by hydride generation based on SM 3114 BC-2005 for As, cold vapor atomic absorption spectrometry based on EPA 245-1 method for $\mathrm{Hg}$, and inductively coupled plasma optical emission spectrometry (ICP-OES model OPTIMA 3000DV-Perkin Elme) based on EPA 200.7 for the other metals. The detection limits were $0.1 \mathrm{mg} / \mathrm{kg}$ for $\mathrm{Cd}, \mathrm{Cu}$, $\mathrm{Cr}$, and $\mathrm{Pb}, 0.05 \mathrm{mg} / \mathrm{kg}$ for As, and $0.02 \mathrm{mg} / \mathrm{kg}$ for $\mathrm{Hg}$. All used reagents were of analytical grade. The efficiency of the analysis was assessed by three replicates. The relative standard deviations obtained varied from 5 to $11 \%$ and are considered satisfactory given the complex nature and the differences between the samples of the sediment matrix.

2.4. Statistical Analysis. Multivariate statistical analysis was applied to the sediment data looking for possible characterization of different pollution sources. Data was processed 
TABLE 1: Metal concentration ( $\mathrm{mg} / \mathrm{kg}$ ), in sediment samples with grain size $<63 \mu \mathrm{m}$ for mainstream of Llapa Subbasin with median, mean, standard deviation, and skew for Y1, Y2, and Y3 (mainstream points); threshold effect level (TEL), and probable below level (PEL).

\begin{tabular}{|c|c|c|c|c|c|c|c|c|c|c|c|}
\hline & Y1 & $\mathrm{Y} 2$ & Y3 & Y4 & Y5 & Median $^{\mathrm{a}}$ & Mean $^{\mathrm{a}}$ & $\mathrm{SD}^{\mathrm{a}}$ & Skew $^{\mathrm{a}}$ & TEL & PEL \\
\hline $\mathrm{pH}$ & 7.30 & 7.60 & 7.68 & $-^{c}$ & 3.44 & 7.60 & 7.53 & 0.2 & -1.4 & - & - \\
\hline $\mathrm{EC}^{\mathrm{b}}$ & 31.00 & 35.00 & 38.00 & 734.00 & 212.00 & 35.00 & 34.67 & 3.5 & -0.4 & - & - \\
\hline AI & 13687.3 & 19378.5 & 12649 & 24522.7 & 15265.5 & 13687.30 & 15238.27 & 3622.9 & 1.6 & - & - \\
\hline As & 5.28 & 2.5 & 53.88 & 22.65 & 350.73 & 5.28 & 20.55 & 28.9 & 1.7 & 5.9 & 17 \\
\hline $\mathrm{Cd}$ & 2.4 & 4 & 3.1 & 3.7 & 11.3 & 3.10 & 3.17 & 0.8 & 0.4 & 0.6 & 3.5 \\
\hline $\mathrm{Cr}$ & 5.4 & 6.8 & 4.3 & 5.7 & 5.5 & 5.40 & 5.50 & 1.3 & 0.4 & 37.3 & 90 \\
\hline $\mathrm{Cu}$ & 10.3 & 133.1 & 63.4 & 502 & 446 & 63.40 & 68.93 & 61.6 & 0.4 & 35.7 & 197 \\
\hline $\mathrm{Fe}$ & 12397.4 & 13930 & 14478 & 17810.4 & 24884.25 & 13930.00 & 13601.80 & 1078.4 & -1.2 & - & - \\
\hline $\mathrm{Hg}$ & n.d. ${ }^{\text {d }}$ & 1.02 & n.d. & n.d. & 1.26 & 0.00 & 0.34 & 0.6 & 1.7 & 0.17 & 0.49 \\
\hline $\mathrm{Mn}$ & 749.3 & 1205.8 & 957.7 & 933.7 & 372.75 & 957.70 & 970.93 & 228.5 & 0.3 & - & - \\
\hline $\mathrm{Ni}$ & 5.9 & 9.4 & 8.4 & 10.5 & 11.6 & 8.40 & 7.90 & 1.8 & -1.2 & - & - \\
\hline $\mathrm{Pb}$ & 8.1 & 20 & 8.9 & 9.5 & 35 & 8.90 & 12.33 & 6.7 & 1.7 & 35 & 91 \\
\hline $\mathrm{Sb}$ & 0.9 & 1.2 & 1.2 & 1.2 & 4.75 & 1.20 & 1.10 & 0.2 & -1.7 & - & - \\
\hline Sn & 64.7 & 93.3 & 71.1 & 65.5 & 85.4 & 71.10 & 76.37 & 15.0 & 1.4 & - & - \\
\hline $\mathrm{Zn}$ & 45 & 90.6 & 76 & 126.1 & 114.65 & 76.00 & 70.53 & 23.3 & -1.0 & 123 & 315 \\
\hline
\end{tabular}

${ }^{\mathrm{a}}$ Calculated for mainstream samples (Y1, Y2, Y3); ${ }^{\mathrm{b}} \mathrm{Ohms}{ }^{*} 1000$; ${ }^{\mathrm{c}}$ no available; ${ }^{\mathrm{d}}$ no detectable (n.d.).

using PCA and HCA $[13,14,43]$ by SPSS v15.0 software package.

First, PCA was applied to the 9 samples, characterized by 13 metal and metalloid concentrations as the sum of the values obtained in each step of the SES. The principal component and eigenvectors of Pearson correlation matrix values were computed. Next, rotation of principal components was carried out using the Varimax normalized algorithm, which facilitates interpretation of the principal component by maximizing the variance of the extracted factors and reducing the uncertainties of initial unrotated factor loading [14]. Varimax rotation was applied to the principal components that contribute more than $5 \%$ of the total variance of the data set. Finally, HCA was applied to the 9 samples, expressed in terms of the four rotated factors. HCA is the most common cluster analysis method in environmental analysis and group samples according to data similarities. The most similar points are grouped in a cluster, and the process is repeated until all points belong to one cluster [38]. Statistical calculations were performed with SPSS v15.0 software package, and decimal logarithm transformation was used to improve the statistical analysis. Kurtosis and skewness statistics indicate that the transformed variables are closer to a normal distribution than the original variables for almost all metal concentrations. A threshold value of $0.001 \mathrm{mg} / \mathrm{kg}$ was set for $\mathrm{Hg}$ and $\mathrm{Sb}$ concentrations for results below concentration detection limits.

\section{Results and Discussion}

3.1. Sediment Metal Content. Different trends were observed between both subbasins. First, the concentration range, median, mean, standard deviation (SD), and skew of trace metal in sediment samples from the mainstream (Y1, Y2, Y3) and tributaries (Y4, Y5) of the Llapa subbasin are presented in Table 1. In this area, tributary sampling points were located in streams flowing directly from the mine site (Figure 1). Table 2 shows the same type of data as Table 1 but for the mainstream (R1, R2, and R3) and tributary (R4) monitoring points in the Rejo subbasin. In this case, R4 was located in a stream that does not come into contact with mine drainage and could therefore be considered nonpolluted.

In the Llapa subbasin (Table 1), concentrations of $\mathrm{Cr}$, $\mathrm{Ni}$, and $\mathrm{Sn}$ did not differ significantly between samples, but differences were observed in the values of $\mathrm{Al}, \mathrm{Fe}$, and $\mathrm{Zn}$. These findings are in agreement with the literature $[44,45]$. Slightly high values were found in Y2, located at the mainstream, and in Y4 and Y5, located at tributaries. Mainstream and the tributary point $\mathrm{Y} 5$ concentrations showed comparatively greater differences of the remaining elements (As, $\mathrm{Cd}, \mathrm{Cu}, \mathrm{Pb}$, and $\mathrm{Sb}$ ). As was more than sixteen times higher in tributaries than in the mainstream, and $\mathrm{Cu}$, for which a ratio of over $8: 1$ was obtained. In Rejo subbasin, concentrations of Al, As, $\mathrm{Cr}, \mathrm{Fe}, \mathrm{Sb}$, and $\mathrm{Sn}$ were similar at all sampling points and small differences were found for $\mathrm{Hg}, \mathrm{Ni}$, and $\mathrm{Pb}$. In contrast, considerable differences were found for $\mathrm{Cu}, \mathrm{Cd}$, and $\mathrm{Zn}$ showing comparatively higher concentrations in R1. Lowest metal concentrations of the whole data set for almost all of the metals were obtained in the R4 tributary.

Taking into consideration that high pollutant concentrations accompanied by high standard deviations suggest anthropogenic sources, pollution due to mining is confirmed for both subbasins. Additionally, metal concentrations from monitoring points near mine sites exceed the levels present in unpolluted areas, such as the tributaries or mainstream. Homogeneous distribution across the site (R4 in Rejo subbasin and Y1, Y2, and Y3 in Llapa subbasin) confirm this concern especially in Llapa subbasin with lower standard deviations. Therefore, mine pollution is present in Llapa subbasin for $\mathrm{As}, \mathrm{Cd}, \mathrm{Cu}, \mathrm{Pb}$, and $\mathrm{Sb}$ and in Rejo subbasin for $\mathrm{Cu}, \mathrm{Cd}$ and $\mathrm{Zn}$. 
TABle 2: Metal concentration ( $\mathrm{mg} / \mathrm{kg}$ ) in sediment samples with grain size $<63 \mu \mathrm{m}$ for tributaries of Rejo subbasin with median, mean, standard deviation and skew for R1, R2, and R3 (mainstream points), threshold effect level (TEL), and probable below level (PEL).

\begin{tabular}{lcccccccccc}
\hline & $\mathrm{R} 1$ & $\mathrm{R} 2$ & $\mathrm{R} 3$ & $\mathrm{R} 4$ & Median $^{\mathrm{a}}$ & Mean $^{\mathrm{a}}$ & SD $^{\mathrm{a}}$ & Skew $^{\mathrm{a}}$ & TEL & PEL \\
\hline $\mathrm{pH}$ & $-{ }^{\mathrm{c}}$ & - & - & - & - & - & - & - & - & - \\
$\mathrm{EC}^{\mathrm{b}}$ & 37 & - & 32 & - & 34.5 & 34.5 & - & - & - & - \\
$\mathrm{AI}$ & 15605 & 13574.6 & 9601.9 & 14330.4 & 13575 & 12927 & 3053.5 & -0.9 & - & - \\
$\mathrm{As}$ & 55.93 & 63.3 & 48.78 & 56.82 & 55.9 & 56 & 7.3 & 0.0 & 5.9 & 17 \\
$\mathrm{Cd}$ & 12.3 & 4.5 & 5.4 & 3.1 & 5.4 & 7.4 & 4.3 & 1.6 & 0.6 & 3.5 \\
$\mathrm{Cr}$ & 3.3 & 7.6 & 4.8 & 6.7 & 4.8 & 5.2 & 2.2 & 0.9 & 37.3 & 90 \\
$\mathrm{Cu}$ & 198 & 34.4 & 42.8 & 16.6 & 42.8 & 91.7 & 92.1 & 1.7 & 35.7 & 197 \\
$\mathrm{Fe}$ & 15360.1 & 16810.3 & 15261 & 14731.7 & 15360.1 & 15810 & 867.3 & 1.7 & - & - \\
$\mathrm{Hg}$ & 0.1 & 0.17 & 0.1 & 0.09 & 0.1 & 0.12 & 0.0 & 1.7 & 0.17 & 0.49 \\
$\mathrm{Mn}$ & 3711.8 & 878.6 & 932.2 & 349.9 & 932.2 & 1841 & 1620.5 & 1.7 & - & - \\
$\mathrm{Ni}$ & 12 & 11.8 & 7 & 6.4 & 11.8 & 10.3 & 2.8 & -1.7 & - & - \\
$\mathrm{Pb}$ & 92.6 & 54.7 & 40.5 & 47.9 & 54.7 & 62.6 & 26.9 & 1.2 & 35 & 91 \\
$\mathrm{Sb}$ & n.d. & n.d. & n.d. & n.d. & - & - & - & - & - & - \\
$\mathrm{Sn}$ & 76.3 & 79.7 & 62.8 & 87.5 & 76.3 & 72.9 & 8.9 & -1.5 & - & - \\
$\mathrm{Zn}$ & 452.7 & 122.2 & 149.9 & 55.3 & 149.9 & 241.6 & 183.3 & 1.7 & 123 & 315 \\
\hline
\end{tabular}

${ }^{a}$ Calculated for mainstream samples (R1, R2, R3); ${ }^{b} \mathrm{Ohms}^{*} 1000$; ${ }^{\mathrm{c}}$ no available; ${ }^{\mathrm{d}}$ no detectable (n.d.).

3.2. Ecological Risk Assessment. The potential toxicological effect of sediment trace metal content was assessed in this section. For this, the sediment concentrations were compared with the concentrations established in the Canadian Sediment Quality Guidelines for the Protection of Aquatic Life [30]. Two levels of ecological risk are considered for sediment samples: the threshold effect level (TEL) below which adverse biological effects are expected to occur rarely, and the probable effect level (PEL) above which adverse effects are expected to occur frequently. The data is summarized in Figure 2. Table 1 shows that concentrations of $\mathrm{Cd}$ and $\mathrm{Cu}$ in the Llapa subbasin were above the PEL in all tributary samples, and concentrations of $\mathrm{Pb}$ and $\mathrm{Zn}$ were above the TEL in $33 \%$ of the tributary samples. In addition, $\mathrm{Hg}$ concentrations were above the PEL in approximately $33 \%$ of both mainstream and tributary samples. As gives values far above PEL for Y5 and downstream from this tributary (Y3) values were also above PEL.

Table 2 shows that concentrations of As in the Rejo subbasin were above the PEL in all samples (mainstream and tributary), while $\mathrm{Cd}$ is above PEL only in mainstream samples. This is congruent with other findings present in the literature [44]. Concentrations of $\mathrm{Cu}, \mathrm{Pb}$, and $\mathrm{Zn}$ were above the PEL in $33 \%$ of the mainstream samples.

In conclusion, according to Canadian guidelines, there is a risk of toxicity to aquatic life by $\mathrm{As}, \mathrm{Cd}, \mathrm{Cu}, \mathrm{Hg}, \mathrm{Pb}$, and $\mathrm{Zn}$ in the studied area. This is particularly frequent for $\mathrm{As}, \mathrm{Cd}$, and $\mathrm{Cu}$ in the Llapa subbasin, whereas considerable toxicological effects caused by $\mathrm{Pb}$ and $\mathrm{Zn}$ are expected in Rejo subbasin. These results are consistent with the total content of trace metals in sediments nearby mine sites, suggesting that mining not only cause pollution, but also affects the aquatic life.

3.3. Sequential Extraction Scheme Analysis. The potential environmental risk posed by heavy metal content in sediments is dependent on both total content and speciation. The concentrations of metals in all monitoring points in each sequential extraction step (acid-extractable, reducible, oxidizable, and residual) are presented in Table 3 and Figure 3. This figure shows the speciation and partitioning of trace metals in sediments from the mainstream and tributaries of the Llapa (Figure 3(a)) and Rejo subbasins (Figure 3(b)). It should be noted that almost the entire content sum of Sn and $\mathrm{Sb}$ is present in the residual fraction in all samples of Llapa and Rejo subbasin, respectively.

Step 1 is considered an indicator of metal reservoir or pollution potential and also provides information of more recent contamination [46]. The results show that $\mathrm{Zn}$ is the most important in this fraction due to its high percentage value in samples R1, R3, Y4, and Y5 (40\%). Similar trends were found for previous work in regions with this type of pollution $[13,14,31]$. Additionally, high contents of $\mathrm{Ni}, \mathrm{Cu}$, and $\mathrm{Cd}$ are also relevant (above 20\%) increasing the potential pollution risk. Therefore, contamination by $\mathrm{Zn}, \mathrm{Ni}, \mathrm{Cu}$, and $\mathrm{Cd}$ could be attributed to mining in its immediate area.

The reducible fraction (Step 2) is related to metals bound to $\mathrm{Mn}$ and $\mathrm{Fe}$ oxyhydroxides, which are released due to their instability under reducing conditions. Previous studies found significant associations between trace metals and Fe and Mn oxides in sediments of regions that receive discharges of industrial effluents [45]. Fe, Zn, Cd, and $\mathrm{Ni}$ account $20 \%$ of the total content in this fraction for all the samples. $\mathrm{Zn}$ and $\mathrm{Cd}$ are primarily due to anthropogenic sources according to sediment metal content analysis and Step 1 . These findings are consistent with contaminated sediments and soils in the literature $[7,8,42]$. The presence in this step could be as a result of continuous input of these metals from mining. Concerning $\mathrm{Fe}$ and $\mathrm{Ni}$ distribution, the highest contents were found at sample points close to mine sites, indicating that this may be attributed to lithogenic and anthropogenic activities. These findings are in agreement with the literature 


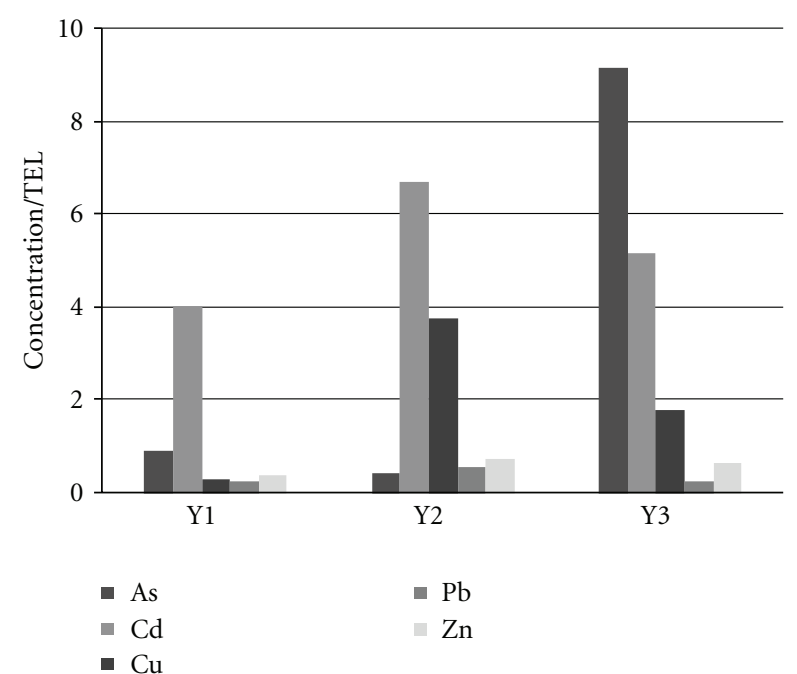

(a)

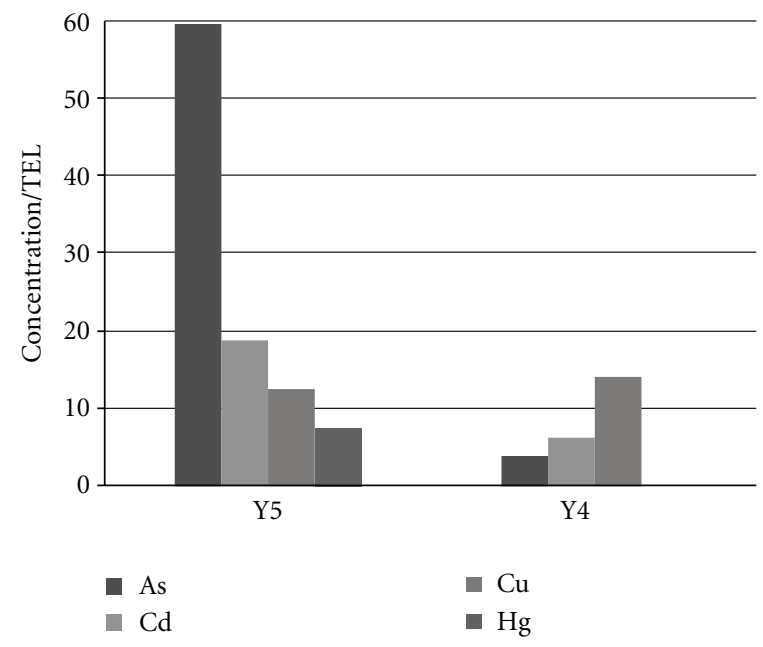

(b)

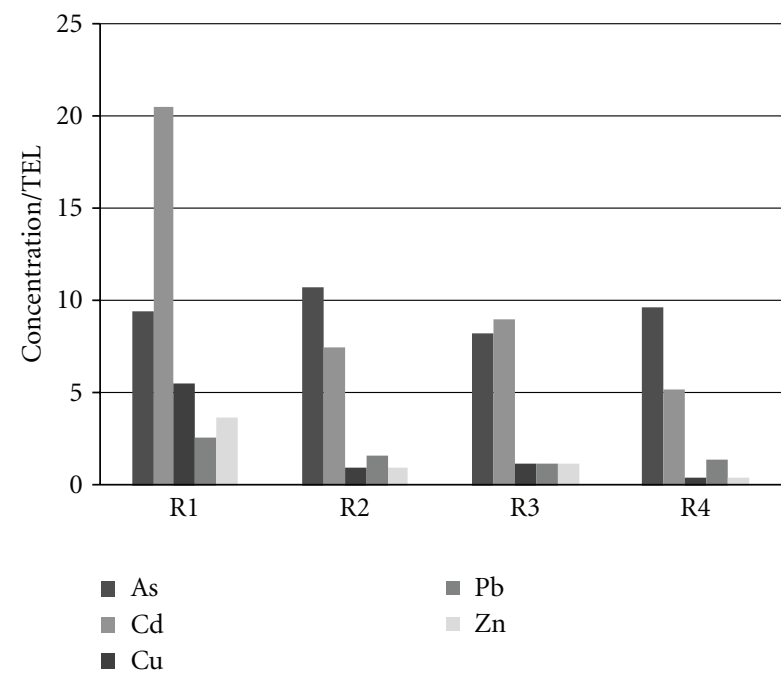

(c)

FIGURE 2: Ratios of trace metals with threshold effect level TEL in sediments from the mainstream (Y1, Y2, Y3) and tributaries (Y4 and Y5) of the Llapa subbasin, and from the mainstream (R1, R2, R3) and tributary (R4) of the Rejo subbasin.

$[14,45,47]$. Approximately $20 \%$ of As is bounded to Fe in Y2 probably adsorbed onto Fe oxy-hydroxides [7]. Approximately $40 \%$ of the total concentration of $\mathrm{Fe}$ and $\mathrm{Sb}$ is present in the second fraction, for the specific case of point Y4, and Y5 in a lesser extent, similar to findings from a contaminated zone due to a mine spill [8]. Downstream from these points, approximately $20 \%$ of Sb is found in the first fraction. $\mathrm{Sb}$ is mainly detected in the residual fraction or bound to oxy-hydroxides due to its low solubility; therefore it is surprising to find a considerable amount of Sb in Step 1. However, low concentrations of Sb are present in this sample, meaning that it does not present an environmental risk.

Trace metals associated with organic material are bound to the oxidizable fraction (Step 3) and may be mobilized by decomposition processes. Metals bound to sulfides might be extracted in this fraction. Considerable percentage of $\mathrm{Hg}$ is related to this fraction (23\%) for all samples from Rejo subbasin, being a significant threat to the environment due to the high toxicity of $\mathrm{Hg}$. $\mathrm{Cr}$ and $\mathrm{Cu}$ are also present in this fraction. It has to be noted that $\mathrm{Hg}$ and $\mathrm{Cr}$ are found in low and homogeneous concentrations in all samples; therefore lithogenic origins can be related to this fraction. The presence of $\mathrm{Cu}$ in the third fraction is only related to Llapa subbasin and R1. Similar to Fe and Ni distribution in Step 2, the presence of $\mathrm{Cu}$ in all the Llapa samples could be related to lithogenic origins, while in $\mathrm{R} 1$ could be primarily related to anthropogenic inputs. Differences between samples for $\mathrm{Cu}$ in this fraction are in agreement with previous work [7, 31, 47].

In summary, the order of relative abundance within the mobile fraction in all the samples (considering the percentage of metals extracted as the sum of the three first fractions) was $\mathrm{Zn}(69 \%)>\mathrm{Ni}(61 \%)>\mathrm{Cu}(58 \%)>\mathrm{Cd}(47 \%)>\mathrm{Fe}$ $(26 \%)>\mathrm{Hg}(23 \%)>\mathrm{Cr}(21 \%)>\mathrm{Al}(15 \%)>\mathrm{Sb}(12 \%)=$ $\mathrm{Pb}(12 \%)>$ As $(2 \%)=\mathrm{Sn}(2 \%)$. Elevated concentrations of metals in residual fractions (low percentage of mobile fraction) indicate that the sediments are relatively unpolluted, 

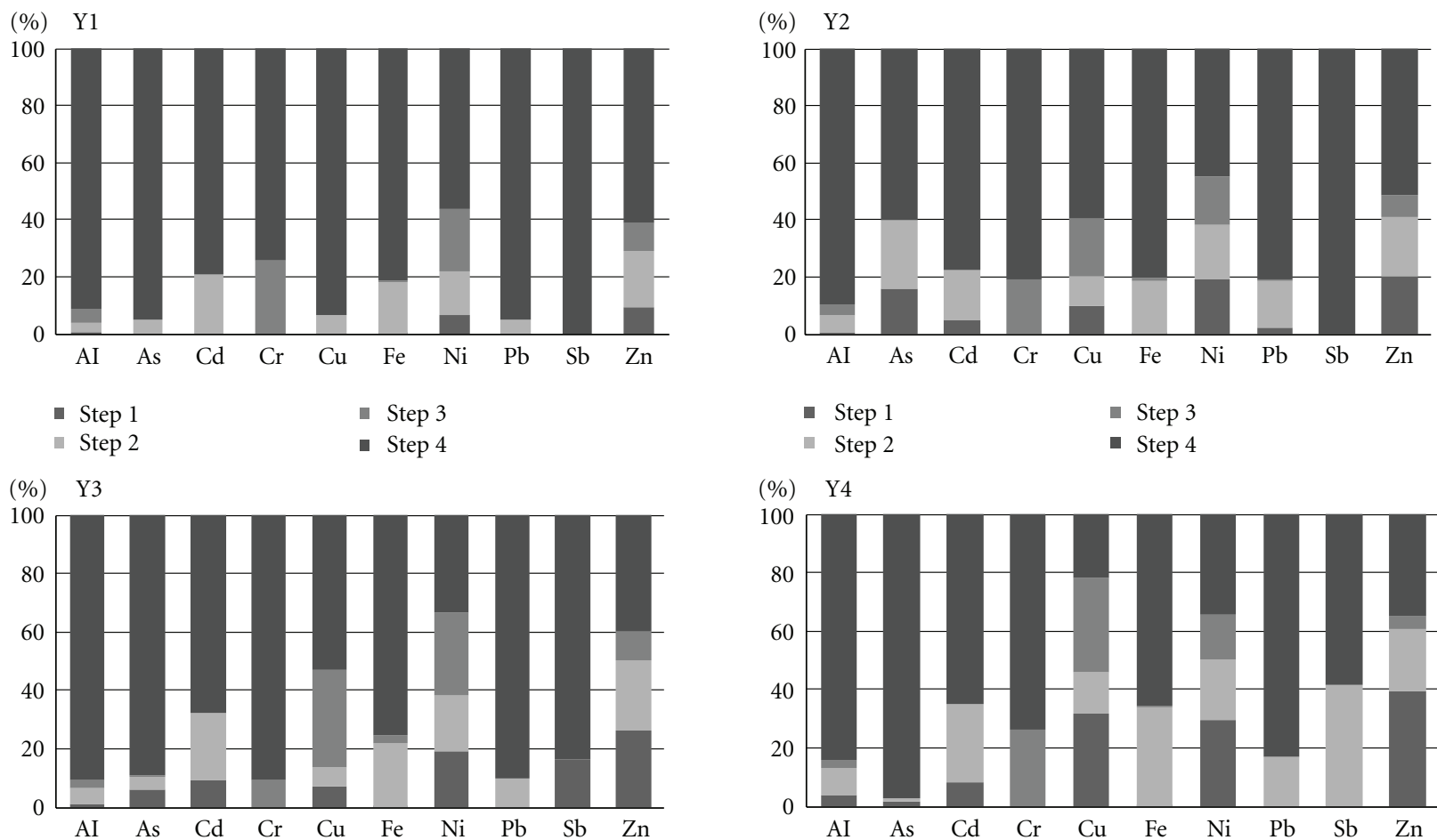

(\%) Y4
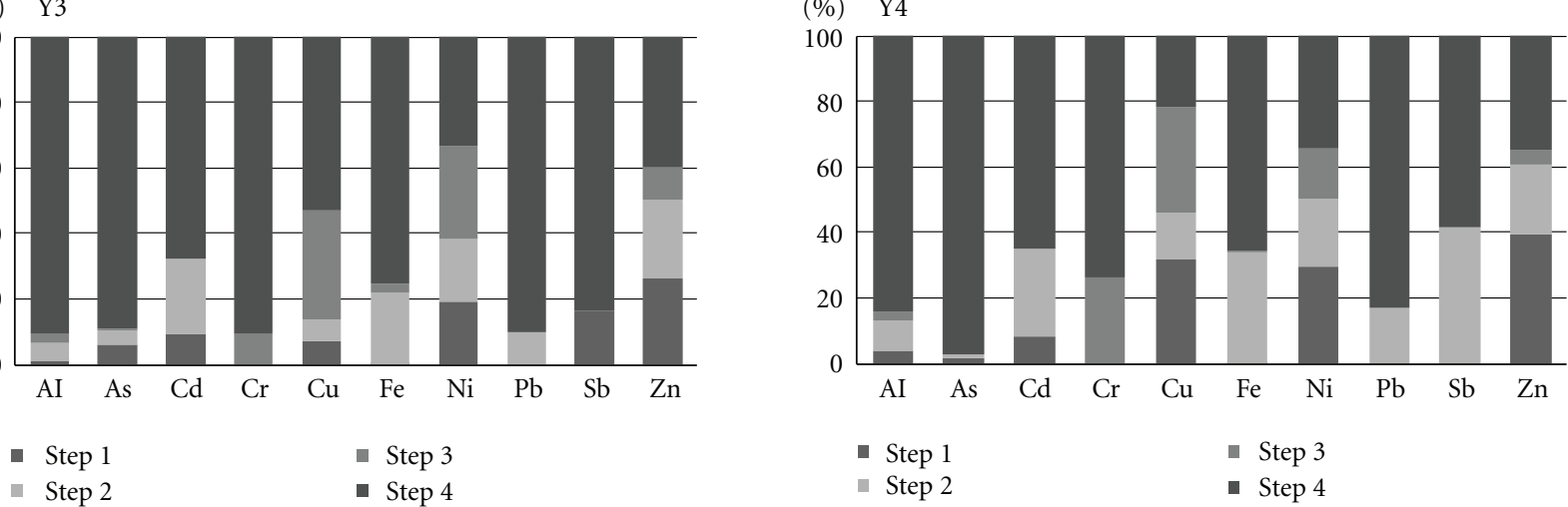

- Step 1

- Step 3

- Step 2

- Step 4

-1 Step 2

- Step 4

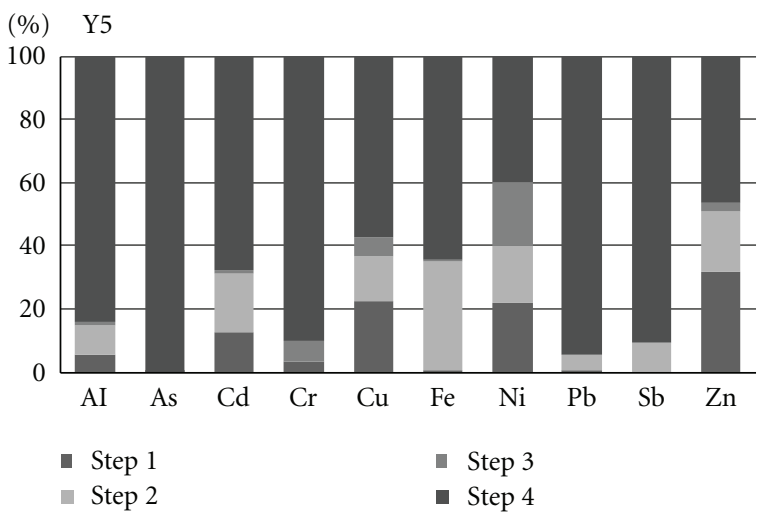

(a)
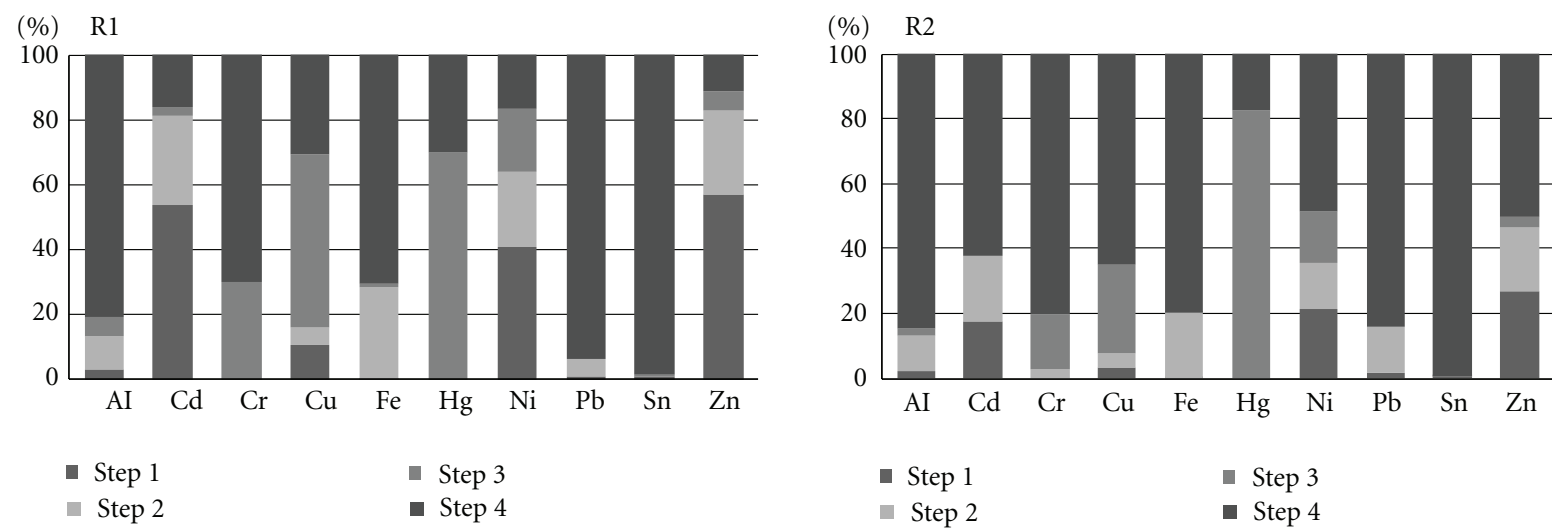

(b)

Figure 3: Continued. 


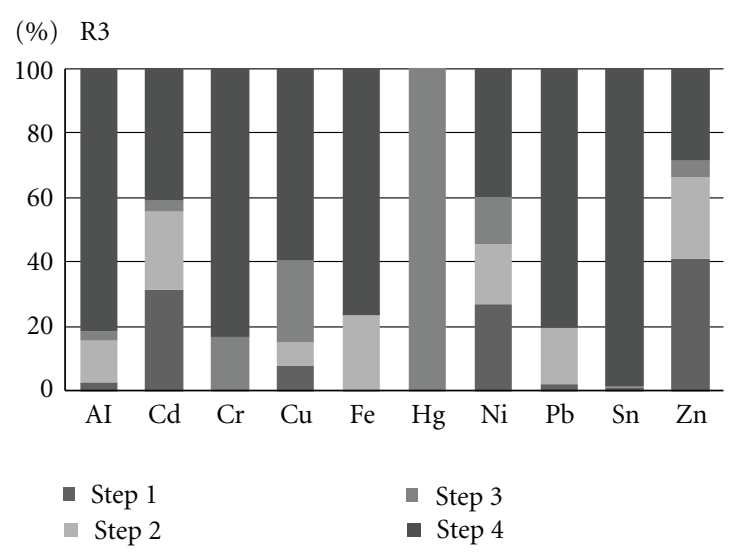

(\%) R4

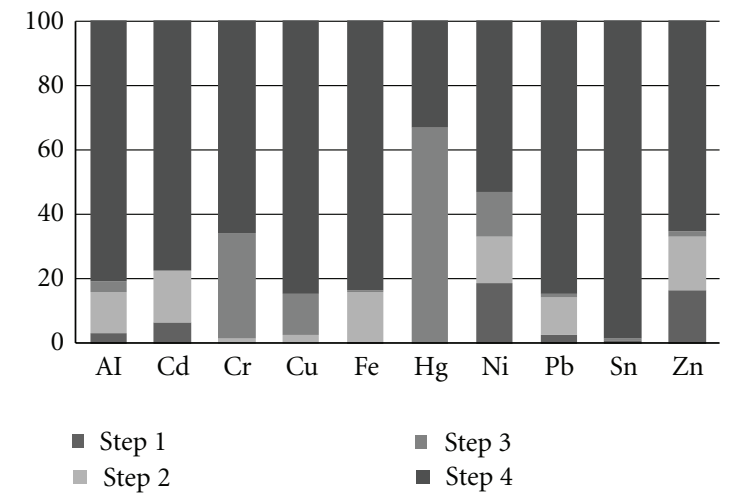

(b)

FIGURE 3: (a) Partitioning of speciation of trace metals in sediments from the mainstream (Y1, Y2, Y3) and tributaries (Y4 and Y5) in the Llapa subbasin. (b) Partitioning of speciation of trace metals in sediments from the mainstream (R1, R2, R3) and tributary (R4) in the Rejo subbasin.

then lithogenic origins can be related to $\mathrm{Al}, \mathrm{Sb}, \mathrm{Pb}, \mathrm{As}$, and Sn [45].

Summarizing, $\mathrm{Zn}, \mathrm{Ni}, \mathrm{Cu}$, and $\mathrm{Cd}$ showed the greatest amounts of trace metals in the bioavailable fractions being a significant threat for the environment. The risk is particularly higher for Rejo than Llapa subbasin where high and available concentrations of $\mathrm{Cd}, \mathrm{Cu}$, and $\mathrm{Hg}$ - and to a lesser extent $\mathrm{Pb}$ and $\mathrm{Zn}$-were found in sediment samples close to mine sites (Tables 1 and 2). The Llapa study area illustrates different behaviors at specific points for As, Fe and $\mathrm{Sb}$ taking into account the main results outlined above (Figure 3 ). However, content of $\mathrm{As}, \mathrm{Fe}$, and $\mathrm{Sb}$ in these related samples are low (Table 1), therefore their presence in movable fractions do not represent an environmental risk. Despite low values given for $\mathrm{Cr}$ and $\mathrm{Hg}$, their availability has to be considered also as a potential risk effect on the environment due to its their specific toxicity, so subsequent studies must be carried out in order to evaluate their environmental risk, especially in Rejo subbasin.

3.4. Statistical Analysis. Table 4 shows loadings of metals on the principal components with the cumulative percentages in each case. The four eigenvalues greater than one were taken into account in further analysis, the others were discarded. These four factors/components accounted for approximately $90 \%$ of the total variance. The corresponding rotated factors were obtained by Kaiser's varimax rotation. All four contributed to a similar extent to the overall variance (from $26.5 \%$ for the first factor to $20 \%$ for the fourth). Table 4 shows the factor scores in terms of 13 metal concentrations for all sediment samples. Communalities $\left(h^{2}\right.$, square of loading) are included; all values are over 0.8 , which confirms the decision to use four factors. Factor 1 is heavily dominated by $\mathrm{Mn}$ and $\mathrm{Zn}$ and by $\mathrm{Cd}, \mathrm{Ni}, \mathrm{Pb}$, and $\mathrm{Cu}$ to a lesser extent. Cr has a negative influence on this first factor, so low values of $\mathrm{Cr}$ correlate with high values of Factor 1. Factor 2 is highly correlated to $\mathrm{As}$ and $\mathrm{Fe}$, and to a lesser extent on $\mathrm{Cd}, \mathrm{Cu}$, and $\mathrm{Ni}$. Factor 3 is dominated by $\mathrm{Sn}$ and $\mathrm{Hg}$, and it also depends on $\mathrm{Pb}$ and $\mathrm{Zn}$. Factor 4 depends heavily on $\mathrm{Al}$ and $\mathrm{Sb}$, less

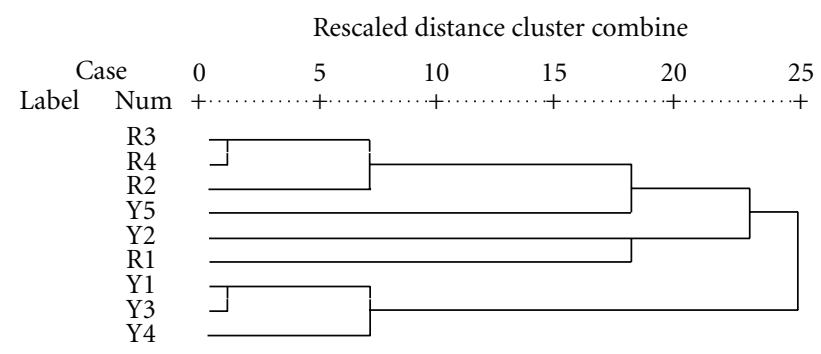

FIGURE 4: Dendogram representing the results of the HCA analysis of sediment samples.

strongly on $\mathrm{Cu}$, and weakly on $\mathrm{Ni}$. $\mathrm{Cr}$ also has a negative influence on Factor 4.

HCA was applied to the nine samples, expressed in terms of the four factors. The dendogram is shown in Figure 4. The largest jump in rescaled distance cluster is found from the values 7 to 18 , see Figure 4 . The members of the five clusters are as follows: Cluster 1 is formed by R2, R4, and R3; Cluster 2 by Y5; Cluster 3 by Y2; Cluster 4 by R1; Cluster 5 by Y1, Y3, and Y4. Note that Cluster 1 only contains sampling points from the Rejo subbasin and Cluster 5 only contains points from Llapa. The results for each sample are expressed in terms of rotated factors in Table 5.

The samples are grouped according to HCA clusters, which help to identify the main characteristics of each one. Clusters 2, 3, and 4 show the highest dependence on the 4 factor loadings (with values of around 2 depending on each cluster), while Clusters 1 and 5 show lower values (less than -1) for all factor loadings. This means that the first set of clusters is characterized by high values of certain metals (each cluster is related to different factors), whereas the second set of clusters is characterized by low values of almost all trace metals. This interpretation of the HCA results suggests that Cluster 1 may represent a characteristic natural profile of metal content in the Rejo subbasin (with relatively low values for most metals, particularly those in Factor 4, 
TABLE 3: Concentrations ( $\mathrm{mg} / \mathrm{kg}$ ) of all the sediment samples in each fraction of the BCR sequential extraction.

\begin{tabular}{|c|c|c|c|c|c|c|c|c|c|c|c|}
\hline Sample & BCR Step & $\mathrm{Al}$ & As & $\mathrm{Cd}$ & $\mathrm{Cu}$ & $\mathrm{Cr}$ & $\mathrm{Fe}$ & $\mathrm{Hg}$ & $\mathrm{Ni}$ & $\mathrm{Pb}$ & $\mathrm{Zn}$ \\
\hline \multirow{4}{*}{ Y1 } & Step 1 & 61.9 & $<0.05$ & $<0.1$ & $<0.1$ & $<0.1$ & 9.2 & $<0.02$ & 0.4 & $<0.1$ & 4.3 \\
\hline & Step 2 & 473 & 0.28 & 0.5 & 0.7 & $<0.1$ & 2212.5 & $<0.02$ & 0.9 & 0.4 & 8.7 \\
\hline & Step 3 & 647.2 & $<0.05$ & $<0.1$ & $<0.1$ & 1.4 & 120.6 & $<0.02$ & 1.3 & $<0.1$ & 4.6 \\
\hline & Step 4 & 12505.2 & 5 & 1.9 & 9.6 & 4 & 10055.1 & $<0.02$ & 3.3 & 7.7 & 27.4 \\
\hline \multirow{4}{*}{ Y2 } & Step 1 & 119.7 & 0.4 & 0.2 & 13.6 & $<0.1$ & 50.6 & $<0.02$ & 1.8 & 0.5 & 18.6 \\
\hline & Step 2 & 1154.7 & 0.6 & 0.7 & 13.4 & $<0.1$ & 2564.7 & $<0.02$ & 1.8 & 3.2 & 18.8 \\
\hline & Step 3 & 716.2 & $<0.05$ & $<0.1$ & 27.0 & 1.3 & 167.5 & 0.02 & 1.6 & 0.1 & 6.6 \\
\hline & Step 4 & 17387.9 & 1.5 & 3.1 & 79.1 & 5.5 & 11147.2 & 1.02 & 4.2 & 16.2 & 46.6 \\
\hline \multirow{4}{*}{ Y3 } & Step 1 & 153.1 & 3.29 & 0.3 & 4.6 & $<0.1$ & 24.3 & $<0.02$ & 1.6 & $<0.1$ & 20 \\
\hline & Step 2 & 675.9 & 2.29 & 0.7 & 4 & $<0.1$ & 3136.9 & $<0.02$ & 1.6 & 0.9 & 18.1 \\
\hline & Step 3 & 381.2 & 0.3 & $<0.1$ & 21.3 & 0.4 & 407.5 & $<0.02$ & 2.4 & $<0.1$ & 7.7 \\
\hline & Step 4 & 11438.8 & 48 & 2.1 & 33.5 & 3.9 & 10909.3 & $<0.02$ & 2.8 & 8 & 30.2 \\
\hline \multirow{4}{*}{ Y4 } & Step 1 & 910.6 & 0.35 & 0.3 & 159.8 & $<0.1$ & 26 & $<0.02$ & 3.1 & $<0.1$ & 49.6 \\
\hline & Step 2 & 2356.1 & 0.3 & 1 & 70.9 & $<0.1$ & 6014 & $<0.02$ & 2.2 & 1.6 & 26.8 \\
\hline & Step 3 & 623.6 & $<0.05$ & $<0.1$ & 161.4 & 1.5 & 108.5 & $<0.02$ & 1.6 & $<0.1$ & 5.9 \\
\hline & Step 4 & 20632.4 & 22 & 2.4 & 109.9 & 4.2 & 11661.9 & $<0.02$ & 3.6 & 7.9 & 43.8 \\
\hline \multirow{4}{*}{ Y5 } & Step 1 & 815.3 & 0.3 & 1.5 & 101.2 & 0.2 & 194.5 & $<0.02$ & 2.55 & 0.2 & 36.8 \\
\hline & Step 2 & 1482.3 & 0.35 & 2.1 & 63.7 & 0.1 & 8542.5 & $<0.02$ & 2.1 & 1.8 & 21.6 \\
\hline & Step 3 & 176 & 0.08 & 0.1 & 26.6 & 0.4 & 75.9 & 0.25 & 2.35 & $<0.1$ & 2.9 \\
\hline & Step 4 & 12792 & 350 & 7.7 & 254.7 & 5.0 & 16071.5 & 1.01 & 4.6 & 33.1 & 53.5 \\
\hline \multirow{4}{*}{$\mathrm{R} 1$} & Step 1 & 509.2 & 0.28 & 6.6 & 20.9 & $<0.1$ & 14.3 & $<0.02$ & 4.9 & 1.1 & 0.6 \\
\hline & Step 2 & 1582.5 & 0.55 & 3.4 & 10.9 & $<0.1$ & 4345.1 & $<0.02$ & 2.8 & 4.7 & 118.7 \\
\hline & Step 3 & 935.8 & $<0.05$ & 0.3 & 106.1 & 1.0 & 191 & 0.07 & 2.3 & $<0.1$ & 0.5 \\
\hline & Step 4 & 12577.5 & 55.1 & 2.0 & 60.1 & 2.3 & 10809.7 & 0.03 & 2 & 86.8 & 75.2 \\
\hline \multirow{4}{*}{ R2 } & Step 1 & 321.5 & 0.24 & 0.8 & 1.1 & $<0.1$ & 13.2 & $<0.02$ & 2.5 & 0.9 & 0.5 \\
\hline & Step 2 & 1470.9 & 1.36 & 0.9 & 1.5 & 0.2 & 3362.4 & $<0.02$ & 1.7 & 7.9 & 23.9 \\
\hline & Step 3 & 307.2 & $<0.05$ & $<0.1$ & 9.5 & 1.3 & 46.9 & 0.14 & 1.9 & $<0.1$ & 0.2 \\
\hline & Step 4 & 11475 & 61.7 & 2.8 & 22.3 & 6.1 & 13387.8 & 0.03 & 5.7 & 45.9 & 79 \\
\hline \multirow{4}{*}{ R3 } & Step 1 & 244.8 & 0.28 & 1.7 & 3.3 & $<0.1$ & 10.1 & $<0.02$ & 1.9 & 0.8 & 61.5 \\
\hline & Step 2 & 1257.4 & 1 & 1.3 & 3.2 & $<0.1$ & 3567.8 & $<0.02$ & 1.3 & 7.1 & 38.3 \\
\hline & Step 3 & 253.3 & $<0.05$ & 0.2 & 10.7 & 0.8 & 51.4 & 0.10 & 1 & $<0.1$ & 6.8 \\
\hline & Step 4 & 7846.4 & 47.5 & 2.2 & 25.6 & 4.0 & 11631.7 & $<0.02$ & 2.8 & 32.6 & 43.3 \\
\hline \multirow{4}{*}{$\mathrm{R} 4$} & Step 1 & 413.9 & 0.36 & 0.2 & $<0.1$ & $<0.1$ & 48.3 & $<0.02$ & 1.2 & 1.2 & 0.7 \\
\hline & Step 2 & 1833.6 & 0.96 & 0.5 & 0.4 & 0.1 & 2293.2 & $<0.02$ & 0.9 & 5.6 & 38.3 \\
\hline & Step 3 & 465.6 & $<0.05$ & $<0.1$ & 2.1 & 2.2 & 70.4 & 0.06 & 0.9 & 0.6 & 0.4 \\
\hline & Step 4 & 11617.3 & 55.5 & 2.4 & 14.1 & 4.4 & 12319.8 & 0.03 & 3.4 & 40.5 & 86.4 \\
\hline
\end{tabular}

with the exception of those in Factor 3), and Cluster 5 a characteristic natural profile of the Llapa subbasin (with relatively low values for most metals, particularly those in Factor 3, with the exception of those in Factor 4). In contrast, the configuration of Clusters 2, 3, and 4 could be related to different sources of pollution in the subbasins (leading to a different relative importance of Factors 1, 3, and 4). Rejo subbasin could be characterized by relatively low natural concentrations of $\mathrm{Al}, \mathrm{Sb}, \mathrm{Cu}$, and $\mathrm{Ni}$, and the Llapa subbasin by relatively low natural concentrations of $\mathrm{Hg}, \mathrm{Pb}$, and $\mathrm{Cr}$, which appears to be consistent with the results in Tables 4 and 5 .

Pollution can be expected in the mainstream of the Rejo subbasin and will increase in areas closer to the source of mine drainage, leading to high concentrations of $\mathrm{Cd}, \mathrm{Cu}$,
$\mathrm{Ni}, \mathrm{Pb}$, and $\mathrm{Zn}$. Two pollution profiles are found in the Llapa subbasin: one in a tributary at the sampling point closest to the mine, where very high concentrations of As, $\mathrm{Cd}, \mathrm{Cu}, \mathrm{Fe}, \mathrm{Ni}$, and $\mathrm{Sb}$ were recorded, and the other in the mainstream located downstream of the tributaries carrying mine drainage, where high concentrations of $\mathrm{Al}, \mathrm{Cu}, \mathrm{Cr}, \mathrm{Hg}$, $\mathrm{Ni}, \mathrm{Pb}$, and $\mathrm{Sn}$ were recorded. $\mathrm{Cu}$ and $\mathrm{Pb}$ are also found in the polluted areas of Rejo subbasin though they do not form part of its expected natural profile. The PCA analysis produces similar results to the previous assessments: low values are recorded at point Y1 in the Llapa subbasin, which is in the mainstream located upstream of the contact with mine drainage, and at point R4 in the Rejo subbasin.

Finally, as explained above, in the Llapa subbasin the $\mathrm{Hg}$ toxicity threshold is exceeded frequently, although relatively 
TABLE 4: Varimax rotated for all sediment samples of the Jequetepeque River basin $(n=13)$. Values below 0.3 are not shown.

\begin{tabular}{|c|c|c|c|c|c|}
\hline \multirow{2}{*}{ Metals } & \multicolumn{4}{|c|}{ Principal component } & \multirow{2}{*}{ Communalities } \\
\hline & 1 & 2 & 3 & 4 & \\
\hline $\mathrm{Zn}$ & 0.932 & & & & 0.981 \\
\hline Mn & 0.922 & -0.342 & & & 0.976 \\
\hline $\mathrm{Cr}$ & -0.702 & & 0.520 & & 0.813 \\
\hline $\mathrm{Ni}$ & 0.541 & 0.448 & 0.364 & 0.465 & 0.842 \\
\hline As & & 0.922 & & & 0.927 \\
\hline $\mathrm{Fe}$ & & 0.910 & & 0.316 & 0.979 \\
\hline $\mathrm{Cd}$ & 0.633 & 0.648 & 0.321 & & 0.924 \\
\hline Sn & & & 0.877 & & 0.825 \\
\hline $\mathrm{Hg}$ & & & 0.873 & & 0.870 \\
\hline $\mathrm{Pb}$ & 0.442 & 0.307 & 0.655 & -0.508 & 0.976 \\
\hline $\mathrm{Al}$ & & & & 0.880 & 0.836 \\
\hline $\mathrm{Sb}$ & -0.336 & & -0.308 & 0.787 & 0.832 \\
\hline $\mathrm{Cu}$ & 0.435 & 0.502 & & 0.705 & 0.946 \\
\hline Eigenvalues & 3.446 & 2.990 & 2.683 & 2.608 & \\
\hline Cumulative $\%$ & 26.504 & 49.506 & 70.148 & 90.208 & \\
\hline
\end{tabular}

TABLE 5: Expressions of samples for each cluster in terms of Varimax rotated factors.

\begin{tabular}{ccccc}
\hline & Factor 1 & Factor 2 & Factor 3 & Factor 4 \\
\hline Cluster 1: & & & & \\
R2 & -0.109 & 0.070 & 0.987 & -0.524 \\
R3 & 0.029 & 0.288 & -0.533 & -1.469 \\
R4 & -1.152 & -0.208 & 0.845 & -0.985 \\
\hline Cluster 2: & & & & \\
Y5 & -0.556 & 2.169 & 0.484 & 0.670 \\
\hline Cluster 3: & & & & \\
Y2 & -0.003 & -1.388 & 1.378 & 1.137 \\
\hline Cluster 4: & & & & \\
R1 & 2.368 & 0.013 & 0.193 & -0.327 \\
\hline Cluster 5: & & & & \\
Y1 & -0.774 & -1.106 & -1.168 & -0.210 \\
Y3 & -0.203 & 0.072 & -1.322 & 0.065 \\
Y4 & 0.141 & 0.090 & -0.864 & 1.643 \\
\hline
\end{tabular}

low values can be expected if we consider the hypothetical natural profile. In the Rejo subbasin, the $\mathrm{Cu}$ toxicity threshold is very likely to be exceeded (in the mainstream), although relatively low values are expected taking into account the hypothetical natural profile. Consequently, the putative link between toxic risk and pollution hotspots is confirmed, at least in the studied area.

\section{Conclusions}

The following conclusions can be drawn from this study.

Sediment samples from the Llapa subbasin showed considerable differences in the concentrations of As, $\mathrm{Sb}, \mathrm{Cd}$, $\mathrm{Cu}, \mathrm{Pb}$, and $\mathrm{Hg}$ between the mainstream and the tributary point Y5 (the closest to the mine). In the Rejo subbasin, considerable differences in the concentrations of $\mathrm{Cd}, \mathrm{Cu}$, and
$\mathrm{Zn}$ were found between mainstream (downstream of flow from the mine site) and tributary samples.

Exposure at aquatic life to toxicity in the studied area is frequently caused by sediment contamination with As, $\mathrm{Cd}, \mathrm{Cu}, \mathrm{Hg}, \mathrm{Pb}$, and $\mathrm{Zn}$. As, $\mathrm{Cd}$, and $\mathrm{Cu}$ concentrations are particularly high in the Llapa subbasin, and $\mathrm{Pb}$ and $\mathrm{Zn}$ concentrations in the Rejo subbasin.

Mobility of the metals, assessed by SES analysis, was $\mathrm{Zn}$ $(69 \%)>\mathrm{Ni}(61 \%)>\mathrm{Cu}(58 \%)>\mathrm{Cd}(47 \%)>\mathrm{Fe}(26 \%)>$ $\mathrm{Hg}(23 \%)>\mathrm{Cr}(21 \%)>\mathrm{Al}(15 \%)>\mathrm{Sb}(12 \%)=\mathrm{Pb}(12 \%)>$ As $(2 \%)=\mathrm{Sn}(2 \%)$. Therefore, $\mathrm{Zn}, \mathrm{Ni}, \mathrm{Cu}$, and $\mathrm{Cd}$ could be considered as a significant threat for the environment in all the monitoring points. In addition, relevant percentages of $\mathrm{Cr}$ and $\mathrm{Hg}$ are available in some points of Rejo subbasin and $\mathrm{As}$, and $\mathrm{Sb}$ in Llapa. The risk is particularly high in the Rejo compared with the Llapa subbasin, where high and available concentrations of $\mathrm{Cd}, \mathrm{Cu}$, and $\mathrm{Hg}$ - and to a lesser extent $\mathrm{Pb}$ and $\mathrm{Zn}$-were found.

Principal component and cluster analyses provide a plausible characterization of the natural (nonpolluted) metal content profiles of the watershed. Besides, sets of metals characteristic of different pollution sources are identified in the two subbasins: (i) pollution can be expected in the mainstream of the Rejo subbasin, particularly at the closest point to the mine drainage, where high concentrations of $\mathrm{Zn}$, $\mathrm{Cr}, \mathrm{Ni}, \mathrm{Cd}, \mathrm{Cu}$, and $\mathrm{Pb}$ were found; (ii) two pollution profiles were identified in the Llapa subbasin: one in a tributary at the closest sampling point to the mine, which shows very high concentrations of $\mathrm{As}, \mathrm{Cd}, \mathrm{Fe}, \mathrm{Ni}$, and $\mathrm{Cu}, \mathrm{s}$ and the other in the mainstream located downstream of the tributaries affected by mine drainage, where high concentrations of $\mathrm{Al}$, $\mathrm{Cu}, \mathrm{Cr}, \mathrm{Hg}, \mathrm{Ni}, \mathrm{Pb}, \mathrm{Sb}$, and $\mathrm{Sn}$ were recorded.

The results of this study are the first step towards a comprehensive evaluation of metal discharges in Jequetepeque River Basin by mining activities. In this sense, their threat to the environment was assessed showing significant impacts in the studied areas.

\section{Acknowledgments}

This research is supported by the Ministerio de Educación y Ciencia, Madrid, CTM 2008-06776C-02, by the Catalan Agency for Development Cooperation (U2006), and by the UPC's Center for Development Cooperation. Thanks are due to Pontificia Universidad Católica del Perú. Thanks are also due to the Cajamarca Regional Government, Nilton Deza, Rebeca Araujo, and GRUFIDES for support in the monitoring process. Thanks are especially due to Maria del Mar Garau for making a specific protocol for this survey.

\section{References}

[1] A. Jarvis and P. Younger, "Broadening the scope of mine water environmental impact assessment: a UK perspective," Environmental Impact Assessment Review, vol. 20, no. 1, pp. 85-96, 2000.

[2] C. Lin, Y. Wu, W. Lu, A. Chen, and Y. Liu, "Water chemistry and ecotoxicity of an acid mine drainage-affected stream in subtropical China during a major flood event," Journal of Hazardous Materials, vol. 142, no. 1-2, pp. 199-207, 2007. 
[3] R. Pérez-López, A. M. Álvarez-Valero, J. M. Nieto, R. Sáez, and J. Matos, "Use of sequential extraction procedure for assessing the environmental impact at regional scale of the São Domingos Mine (Iberian Pyrite Belt)," Applied Geochemistry, vol. 23, no. 12, pp. 3452-3463, 2008.

[4] A. Romero, I. González, and E. Galán, "Estimation of potential pollution of waste mining dumps at Peña del Hierro (Pyrite Belt, SW Spain) as a base for future mitigation actions," Applied Geochemistry, vol. 21, no. 7, pp. 1093-1108, 2006.

[5] N. H. Tarras-Wahlberg and L. T. Nguyen, "Environmental regulatory failure and metal contamination at the Giap Lai pyrite mine, Northern Vietnam," Journal of Environmental Management, vol. 86, no. 4, pp. 712-720, 2008.

[6] M. G. Macklin, P. A. Brewer, K. A. Hudson-Edwards et al., "A geomorphological approach to the management of rivers contaminated by metal mining," Geomorphology, vol. 79, no. 3-4, pp. 423-447, 2006.

[7] E. Galán, J. L. Gómez-Ariza, I. González, J. C. FernándezCaliani, E. Morales et al., "Heavy metal partitioning in river sediments severely polluted by acid mine drainage in the Iberian Pyrite Belt," Applied Geochemistry, vol. 18, no. 3, pp. 409-421, 2003.

[8] U. Kraus and J. Wiegand, "Long-term effects of the Aznalcóllar mine spill-heavy metal content and mobility in soils and sediments of the Guadiamar river valley (SW Spain)," Science of the Total Environment, vol. 367, no. 2-3, pp. 855-871, 2006.

[9] C. R. Cánovas, M. Olías, J. M. Nieto, A. M. Sarmiento, and J. C. Cerón, "Hydrogeochemical characteristics of the Tinto and Odiel Rivers (SW Spain). Factors controlling metal contents," Science of the Total Environment, vol. 373, no. 1, pp. 363-382, 2007.

[10] C. R. Cánovas, C. G. Hubbard, M. Olías, J. M. Nieto, S. Black, and M. L. Coleman, "Hydrochemical variations and contaminant load in the Río Tinto (Spain) during flood events," Journal of Hydrology, vol. 350, no. 1-2, pp. 25-40, 2008.

[11] A. Bebbington, M. Connarty, W. Coxshal, H. O'Shaughnessy, and M. Williams, Mining and Development in Peru, Peru Support Group, Peru, Lima, 2007.

[12] M. B. Arain, T. G. Kazi, M. K. Jamali et al., "Time saving modified BCR sequential extraction procedure for the fraction of $\mathrm{Cd}, \mathrm{Cr}, \mathrm{Cu}, \mathrm{Ni}, \mathrm{Pb}$ and $\mathrm{Zn}$ in sediment samples of polluted lake," Journal of Hazardous Materials, vol. 160, no. 1, pp. 235239, 2008.

[13] Ş. Kartal, Z. Aydin, and Ş. Tokalioğlu, "Fractionation of metals in street sediment samples by using the BCR sequential extraction procedure and multivariate statistical elucidation of the data," Journal of Hazardous Materials, vol. 136, no. 1, pp. 80-89, 2006.

[14] G. Pérez and M. Valiente, "Determination of pollution trends in an abandoned mining site by application of a multivariate statistical analysis to heavy metals fractionation using SM\&TSES," Journal of Environmental Monitoring, vol. 7, no. 1, pp. 29-36, 2005.

[15] A. Sahuquillo, J. F. López-Sánchez, R. Rubio et al., "Use of a certified reference material for extractable trace metals to assess sources of uncertainty in the BCR three-stage sequential extraction procedure," Analytica Chimica Acta, vol. 382, no. 3, pp. 317-327, 1999.

[16] R. P. Thomas, A. M. Ure, C. M. Davidson et al., "Threestage sequential extraction procedure for the determination of metals in river sediments," Analytica Chimica Acta, vol. 286, no. 3, pp. 423-429, 1999.

[17] F. Nannoni, G. Protano, and F. Riccobono, "Fractionation and geochemical mobility of heavy elements in soils of a mining area in northern Kosovo," Geoderma, vol. 161, no. 1-2, pp. 6373, 2011.

[18] F. Pagnanelli, E. Moscardini, V. Giuliano, and L. Toro, "Sequential extraction of heavy metals in river sediments of an abandoned pyrite mining area: pollution detection and affinity series," Environmental Pollution, vol. 132, no. 2, pp. 189-201, 2004.

[19] J. Routh and P. Hjelmquist, "Distribution of arsenic and its mobility in shallow aquifer sediments from Ambikanagar, West Bengal, India," Applied Geochemistry, vol. 26, no. 4, pp. 505-515, 2011.

[20] A. M. Ure, P. H. Quevauviller, H. Muntau, and B. Griepink, "Speciation of heavy metals in soils and sediments. An account of the improvement and harmonization of extraction techniques undertaken under the auspices of the BCR of the comission of the European Communities," International Journal of Environmental Analitical Chemistry, vol. 51, pp. 135151, 1993.

[21] E. V. V. Varejão, C. R. Bellato, M. P. F. Fontes, and J. W. V. Mello, "Arsenic and trace metals in river water and sediments from the southeast portion of the Iron Quadrangle, Brazil," Environmental Monitoring and Assessment, vol. 172, no. 1-4, pp. 631-642, 2011.

[22] B. Villalobos-Castañeda, R. Alfaro-Cuevas, R. CortésMartínez, V. Martínez-Miranda, and L. Márquez-Benavides, "Distribution and partitioning of iron, zinc, and arsenic in surface sediments in the Grande River mouth to Cuitzeo Lake, Mexico," Environmental Monitoring and Assessment, vol. 166, no. 1-4, pp. 331-346, 2010.

[23] U.S. Environmental Protection Agency (USEPA), "Mine drainage control from metal mines in a subalpine environment," Tech. Rep. 60012-77-224, 1977.

[24] U.S. Environmental Protection Agency (USEPA), "Quality Assurance/Quality Control (QA/QC) for 301(h) monitoring programs: guidance on field and laboratory methods," Tech. Rep. 430/9-86-004, 1987.

[25] U.S. Environmental Protection Agency (USEPA), "Methods for measuring the acute toxicity of effluents and receiving waters to freshwater and marine organisms," Tech. Rep. 600/490/027F, Cincinnati, Ohio, USA, 1991.

[26] U.S. Environmental Protection Agency (USEPA), "Methods for the determination of metals in environmental samples," Tech. Rep. 600/R-94/111, 1994.

[27] U.S. Environmental Protection Agency (USEPA), "Contaminated sediment management strategy," Tech. Rep. 823-R-98001, Office of Water, Washington, DC, USA, 1998.

[28] U.S. Environmental Protection Agency (USEPA), "Methods for collection, storage and manipulation of sediments for chemical and toxicological analyses: technical manual," Tech. Rep. 823-B-01-002, 2001.

[29] U.S. Environmental Protection Agency (USEPA), "Guidance on choosing a sampling design for environmental data collection," Tech. Rep. 240/R-02/005, 2002.

[30] Canadian Council of Ministers of the Environment (CCME), Canadian Sediment Quality Guidelines for the Protection of Aquatic Life. Summary Tables, Canada, Ottawa, 2002.

[31] Z. F. Yang, Y. Wang, Z. Y. Shen, J. F. Niu, and Z. W. Tang, "Distribution and speciation of heavy metals in sediments from the mainstream, tributaries, and lakes of the Yangtze River catchment of Wuhan, China," Journal of Hazardous Materials, vol. 166, no. 2-3, pp. 1186-1194, 2009.

[32] CARE World Wide Fund for Nature, "Gesellschaft für technische zusammenarbeit," International Institut for Environment and Developmnet. Centro Ecumenico de Acción y Promoción 
Socia, Proyecto Compensación Equitativa por Servicios Ambientales Hidrológicos (CESAH), Cajamarca, Peru, 2007.

[33] CAO Compliance Advisor Ombudsman for the International Finance Corporation (IFC) and Multilateral Investment Guarantee Agency (MIGA), "Participatory water monitoring (2004-2006). Cajamarca".

[34] DIGESA; Dirección general de salud ambiental Ministerio de Salud, "Gobierno Regional de Cajamarca, DESA," Cajamarca saludable II. Perú, 2008.

[35] PEJEZA Proyecto Especial Jequetepeque-Zaña and Instituto Nacional de Recursos Naturales del Ministerio de Agricultura (INRENA), "Plan de ordenamiento, manejo ambiental y Desarrollo Social en la Cuenca media y Alta del Rió Jequetepeque para la protección del embalse Gallito Ciego," Tech. Rep., Cajamarca, Perú, 2005.

[36] Stratus Consulting INC, "Reporte de la Evaluación independiente de la calidad y cantidad del agua en la cercanía del distrito minero Yanacocha," Tech. Rep., Cajamarca, Perú, 2003.

[37] J. M. Casas, H. Rosas, M. Solé, and C. Lao, "Heavy metals and metalloids in sediments from the Llobregat basin, Spain," Environmental Geology, vol. 44, no. 3, pp. 325-332, 2003.

[38] A. M. Idris, "Combining multivariate analysis and geochemical approaches for assessing heavy metal level in sediments from Sudanese harbors along the Red Sea coast," Microchemical Journal, vol. 90, no. 2, pp. 159-163, 2008.

[39] M. Fukue, M. Yanai, Y. Sato, T. Fujikawa, Y. Furukawa, and S. Tani, "Background values for evaluation of heavy metal contamination in sediments," Journal of Hazardous Materials, vol. 136, no. 1, pp. 111-119, 2006.

[40] M. I. Prudêncio, M. I. Gonzalez, M. I. Dias, E. Galán, and F. Ruiz, "Geochemistry of sediments from El Melah lagoon (NE Tunisia): a contribution for the evaluation of anthropogenic inputs," Journal of Arid Environments, vol. 69, no. 2, pp. 285298, 2007.

[41] E. V. V. Varejão, C. R. Bellato, and M. P. F. Fontes, "Mercury fractionation in stream sediments from the Quadrilátero Ferrífero gold mining region, Minas Gerais State, Brazil," Environmental Monitoring and Assessment, vol. 157, no. 1-4, pp. 125-135, 2009.

[42] M. Pueyo, J. Mateu, A. Rigol, M. Vidal, J. F. López-Sánchez, and G. Rauret, "Use of the modified BCR three-step sequential extraction procedure for the study of trace element dynamics in contaminated soils," Environmental Pollution, vol. 152, no. 2, pp. 330-341, 2008.

[43] Y. M. Han, P. X. Du, J. J. Cao, and E. S. Posmentier, "Multivariate analysis of heavy metal contamination in urban dusts of Xi' an, Central China," Science of the Total Environment, vol. 355, no. 1-3, pp. 176-186, 2006.

[44] H. Y. Doaa and F. E.-S. Ghada, "Assessment of some heavy metals in surface sediments of the Aqaba Gulf, Egypt," Environmental Monitoring and Assessment, vol. 180, no. 1-4, pp. 229-242, 2011.

[45] E. A. Passos, J. C. Alves, I. S. dos Santos, J. H. Alves, C. A. Garcia, and A. S. Costa, "Assessment of trace metals contamination in estuarine sediments using a sequential extraction technique and principal component analysis," Microchemical Journal, vol. 96, no. 1, pp. 50-57, 2010.

[46] G. Rauret, "Extraction procedures for the determination of heavy metals in contaminated soil and sediment," Talanta, vol. 46, no. 3, pp. 449-455, 1998.

[47] L. Medici, J. Bellanova, C. Belviso et al., "Trace metals speciation in sediments of the Basento River (Italy)," Applied Clay Science, vol. 53, no. 3, pp. 414-442, 2011. 


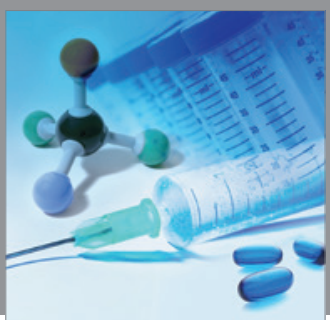

International Journal of

Medicinal Chemistry

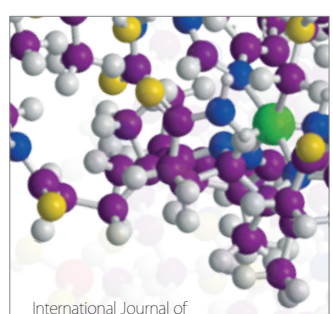

Carbohydrate Chemistry

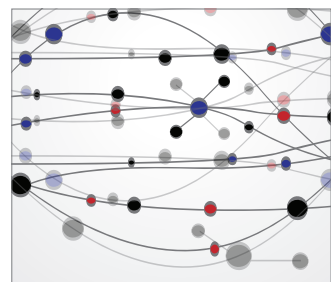

The Scientific World Journal
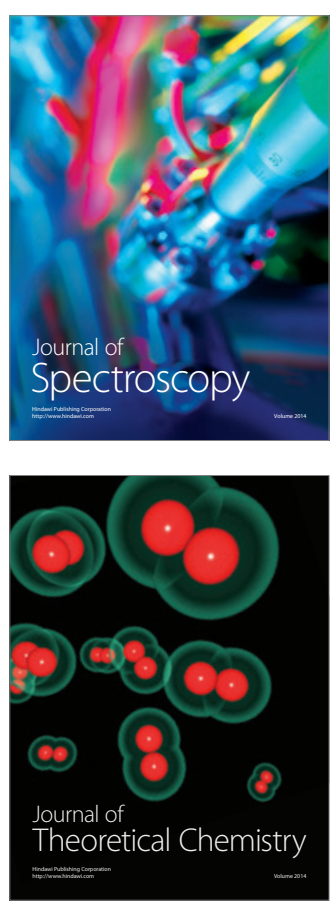
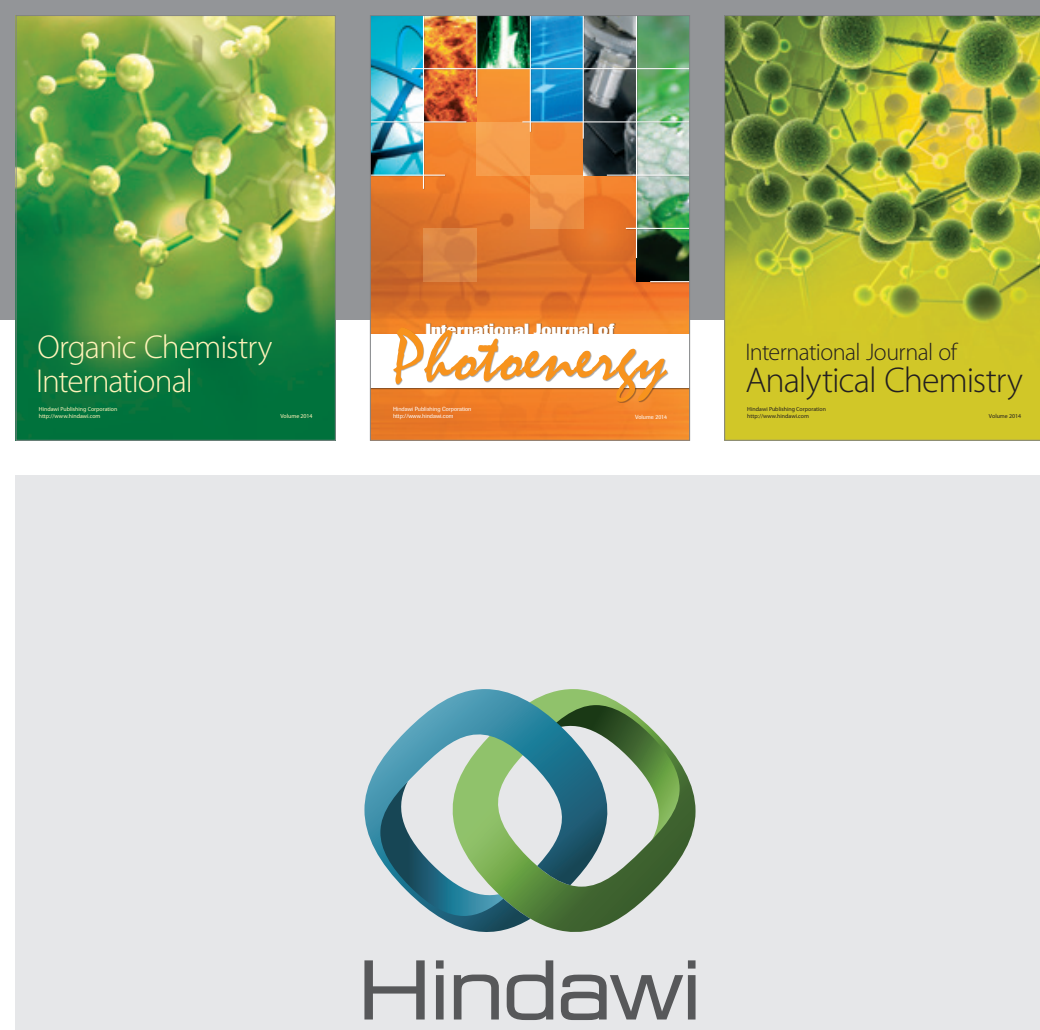

Submit your manuscripts at

http://www.hindawi.com
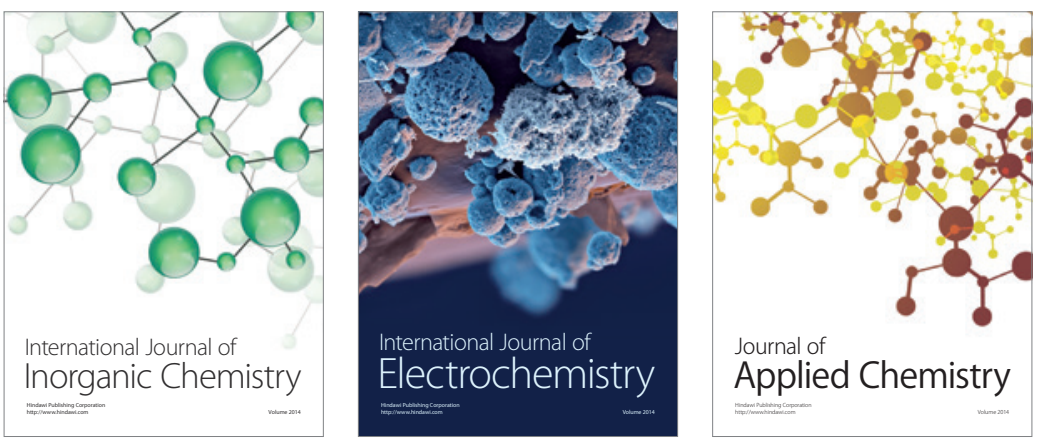

Journal of

Applied Chemistry
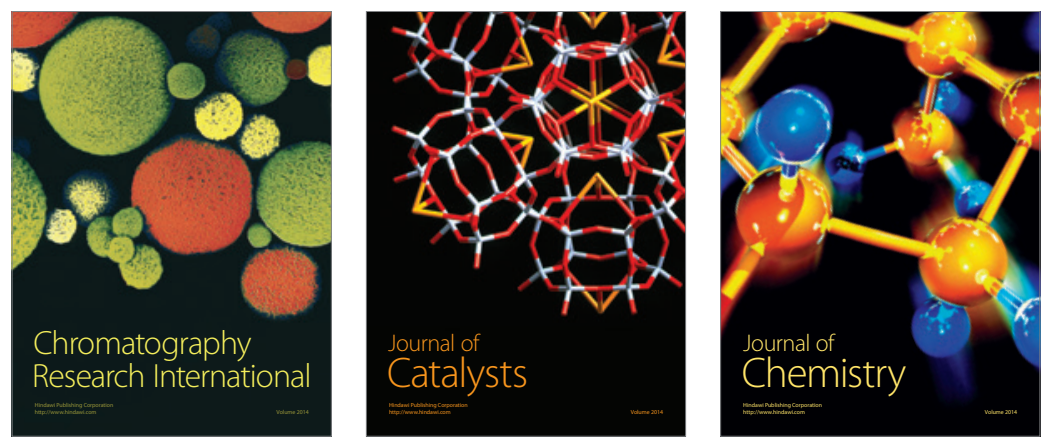
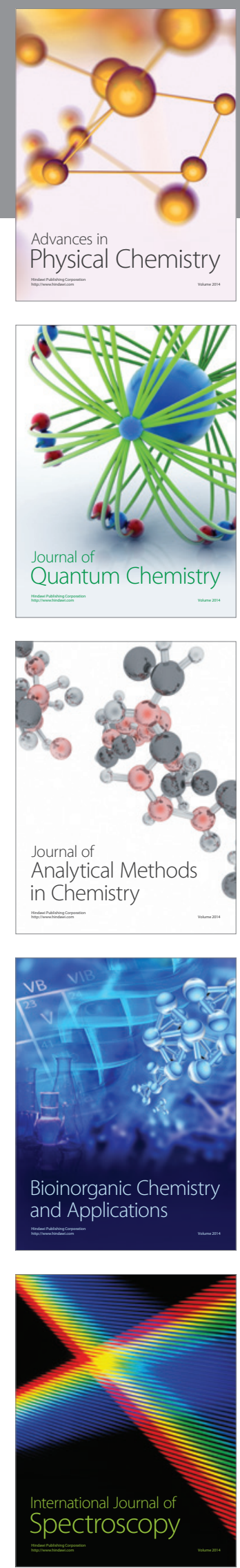